\title{
Case Study: Differences Between US And International Financial Statements
}

Dolores Rinke, Purdue University Calumet, USA

\begin{abstract}
This case examines the differences in format and terminology in financial statements between US Generally Accepted Accounting Principles (GAAP) and International Financial Reporting Standards (IFRS). Students download the financial statements of two different companies in the same industry; i.e., Nokia (reporting under IFRS) and Motorola (reporting under US GAAP). Questions related to the differences in format and terminology are addressed.
\end{abstract}

Keywords: US Generally Accepted Accounting Principles (GAAP); International Financial Reporting Standards (IFRS); Convergence

\section{INTRODUCTION}

n order to achieve a single set of high-quality, globally accepted accounting standards, the Financial Accounting Standards Board (FASB) and International Accounting Standards Board (IASB) have been working together on convergence since 2002 (after the Norwalk Agreement). In November of 2008, the
Security and Exchange Commission (SEC) proposed a roadmap for a possible process to adopt International Reporting Standards (IFRS) in the United States (US).

In February of 2010, the SEC issued a statement which fully supports a single set of accounting standards and encouraged the convergence of the US Generally Accepted Accounting Principles (GAAP) and the IFRS.

The SEC ordered its staff to execute a work plan before transitioning from the current financial reporting system for US companies to IFRS. The work plan includes the following areas of consideration:

- $\quad$ Development and application of IFRS for US reporting companies;

- Independence of standard setting for the benefit of investors;

- $\quad$ Investor understanding and education about IFRS;

- $\quad$ Effects of IFRS over US regulatory environment;

- $\quad$ Effects of IFRS on US companies in terms of accounting systems, contacts, corporate governance, and contingencies;

- $\quad$ Readiness of human resources.

\section{MOTOROLA AND NOKIA}

Motorola is a US telecommunications company based in Schaumburg, Illinois. It is a manufacturer of wireless telephone handsets, also designing and selling wireless network infrastructure equipment, such as cellular transmission base stations and signal amplifiers. Motorola's home and broadcast network products include set-top boxes, digital video recorders, and network equipment used to enable video broadcasting, computer telephony, and high-definition television. Its business and government customers consist mainly of wireless voice and broadband systems used to build private networks and public safety communications systems.

Nokia Corporation is a Finnish multinational communications corporation that is headquartered near Finland's capital, Helsinki. Nokia is engaged in the manufacturing of mobile devices and in converging Internet and 
communications industries. Nokia offers Internet services, such as applications, games, music, maps, media and messaging through its Ovi platform. Nokia is also actively involved in international R \& D cooperation, including the development of the standards for third generation mobile telephony which has made Nokia the highest selling mobile phone vendor within the last few years.

\section{QUESTIONS FOR THE CASE STUDY}

Go to the respective websites of these two companies and download the financial statements of Nokia (reporting under IFRS) and Motorola (reporting under GAAP). After reviewing the financial statements, answer the following questions related to the differences in format and terminology of the financial statements:

1. Under IFRS, what is the preferred name for the Balance Sheet?

2. How does an IFRS Balance Sheet differ from the GAAP Balance Sheet in terms of terminology? Note at least three differences.

3. How does an IFRS Balance Sheet differ from the GAAP Balance Sheet in terms of placement (the ordering of items)?

4. $\quad$ List at least three differences in equity terminology under GAAP and IFRS.

5. What is the preferred name for the Income Statement under IFRS?

6. How does an IFRS "Income Statement" differ from the GAAP Income Statement in terms of terminology? Note at least three differences.

7. How does an IFRS "Income Statement" differ from the GAAP Income Statement in terms of placement (the ordering of items)?

\section{INSTRUCTOR'S NOTES}

This case provides an interesting examination of the upcoming mandate that companies listed in the US report under IFRS. Companies can start planning and preparing now for a timely successful conversion. This case can be used in the introductory or intermediate accounting courses. It is designed to be conducted as either a homework assignment or in-class project during a one or two-hour class.

\section{AUTHOR INFORMATION}

Dolores Rinke is a Certified Public Accountant (CPA) and a professor at Purdue University Calumet where she teaches financial and international accounting. She is also a Fulbright Scholar and served as Treasurer for the Fulbright Association in Washington, D.C. for six years. Her professional experience includes work with General Motors Corporation, the University of Michigan, Chicago World Trade Organization and KPMG's Capital Development Project for the country of Latvia. E-mail: dfrinke@ purduecal.edu 